STUDIA I PRACE WYDZIAKU NAUK EKONOMICZNYCH I ZARZĄDZANIA NR 40, T. 2

DOI: $10.18276 / \operatorname{sip} .2015 .40 / 2-08$

Jolanta Kondratowicz-Pozorska*

Politechnika Koszalińska

\title{
ROLA ROLNICTWA W KREOWANIU TRWAŁEGO ROZWOJU
}

\section{STRESZCZENIE}

W artykule przedstawiono wkład rolnictwa w tworzenie trwałego rozwoju. Analizę przeprowadzono w ujęciach ekonomicznym, społecznym i środowiskowym.

Słowa kluczowe: zrównoważone rolnictwo, zrównoważony rozwój, funkcje rolnictwa

\section{Wprowadzenie}

W gospodarce wyróżnia się trzy sektory: rolnictwo, przemysł i usługi. Dwa ostatnie z wymienionych są przedmiotem specjalnego zainteresowania ze strony ekonomistów, natomiast rolnictwo i jego rola są wręcz marginalizowane ${ }^{1}$. Jest to spowodowane miarami aktywności gospodarczej, które stosuje się do oceny konkurencyjności gospodarek. Szczególną misję wśród nich przypisuje się PKB - mierze preferującej tę gospodarkę lub ten sektor, która z roku na rok powiększa rozmiary produkcji.

W latach 2012-2014 w krajach wysoko rozwiniętych udział rolnictwa w tworzeniu PKB wynosił ok. 3\% (w Europie jest nawet kilka krajów, w których udział

\footnotetext{
Adres e-mail: ap@gryf.pl.

1 J. Haman, R. Hołownicki, R. Michałek, J. Żmija, Misja nauk rolniczych w rozwoju polskiego sektora rolno-spożywczego, „Inżynieria Rolnicza” 2012, z. 4 (139), t. 1, s. 465-480.
} 
rolnictwa w PKB spadł poniżej 1\%, np. Niemcy, Szwajcaria i Wielka Brytania) ${ }^{2}$, natomiast w państwach rozwijających - sięgał nawet 50\% (Sierra Leone). Przyjęto zatem, że im lepiej rozwinięte państwo, tym mniejsza rola rolnictwa w jego gospodarce. Nasuwa się więc pytanie: czy rzeczywiście w przyszłości rolnictwo nie będzie miało żadnego znaczenia dla rozwoju gospodarczego i społecznego?

Celem prezentowanych rozważań jest wieloaspektowe przedstawienie roli rolnictwa w gospodarce, a przede wszystkim opisanie relacji przyczynowo-skutkowych pomiędzy działalnością rolniczą a utrzymaniem warunków niezbędnych do zapewnienia trwałego, zrównoważonego rozwoju (ZR). Dla realizacji przyjętego kierunku badań zgromadzono i wykorzystano wtórne dane statystyczne, dokonano przeglądu literatury krajowej i międzynarodowej.

\section{Funkcje współczesnego rolnictwa}

Według ekonomistów rolnictwa, ingerencja państwa w ten sektor wynika z jego szczególnej roli w gospodarce, a także ze znaczenia poszczególnych czynników produkcji zaangażowanych do produkcji rolnej, jak i z samego charakteru gospodarstw rolnych jako podmiotów gospodarczych. Współczesne rolnictwo spełnia przede wszystkim funkcje ${ }^{3}$ :

a) produkcyjną, która polega na wytwarzaniu żywności i produktów nieżywnościowych. Na tym szczeblu ważne są zarówno parametry ilościowe, jak i jakościowe, oraz ich zróżnicowanie, w tym kwestie bezpieczeństwa żywnościowego. Funkcje produkcyjne rolnictwa podyktowane są zarówno wymaganiami konsumentów, jak i zmianami w agrobiznesie i systemach dystrybucji towarów. Niosą one ze sobą skutki społeczne związane z wykorzystaniem zasobów i określają miejsce i rolę rolnictwa w gospodarce narodowej;

b) środowiskowo-przestrzenną, która odnosi się do sposobu wykorzystania środowiska, jakości krajobrazu, obecności skażeń środowiskowych, ochrony przyrody i bioróżnorodności. Zakres i sposób wykorzystania ziemi, intensywność gospodarowania rolniczego, a także relacje między wykorzysta-

2 J. Wilkin, Wilkin o 25-leciu: polskie rolnictwo opłaca się dotować, http://wyborcza.pl/1,91446, 16068282,Wilkin_o_25_leciu_polskie_rolnictwo_oplaca_sie_dotowac.html\#ixzz3WoHqZEaI (dostęp 8.04.2015).

${ }^{3}$ M. Adamowicz, Wielofunkcyjne rolnictwo w rozwoju obszarów wiejskich, w: Rolnictwo a rozwój obszarów wiejskich, red. M. Kłodziński, W. Dziun, IRWiR PAN, Warszawa 2005, s. 32-57. 
niem przestrzeni dla celów gospodarczych związanych z ochroną przyrody podlegają oddziaływaniu decyzji poszczególnych podmiotów gospodarczych, jak też polityki w skali centralnej, regionalnej i lokalnej;

c) usługową, związaną z wkładem rolnictwa w utrzymanie produktywności zasobów ziemi oraz bogactwa środowiska naturalnego i społecznego dla potrzeb rozwoju ekonomiczno-społecznego, zatrudnienia istniejących zasobów pracy, właściwego gospodarowania odpadami, a także dla zachowania równowagi między sferą środowiskową, ekonomiczną i społeczną.

Inny zestaw zadań dla rolnictwa, które są realizowane w ramach wdrażania polityki rolnictwa wielofunkcyjnego, zaproponował T. Hunek. Zadania rolnictwa połączono z korzyściami, jakie wynikają z walorów naturalnych terenów wiejskich. Ostatecznie wyróżniono funkcje ${ }^{4}$ :

a) produkcyjną;

b) regionalną, polegającą na utrzymaniu pewnej minimalnej gęstości zaludnienia na wsi, będącej podstawą w przyszłości do rozwoju działalności pozarolniczej;

c) ekologiczną, która przejawia się w tym, że rolnicy są jedyną grupą, która może w odpowiedni sposób zajmować się ziemią; uznano, że im bardziej gospodarka na danym obszarze jest intensywna, tym bardziej efekty zewnętrzne na danym obszarze są negatywne - gdy gospodarka jest ekstensywna, to jej skutki są bardziej pozytywne dla środowiska;

d) kształtowania krajobrazu;

e) ochrony środowiska, dzięki eliminacji zanieczyszczeń, a także utrzymaniu odpowiedniej kultury upraw i zachowaniu terenów zielonych;

f) surowcową i energetyczną: rolnictwo dostarcza surowców odnawialnych i materiałów energetycznych;

g) turystyczno-wypoczynkową - rolnictwo nie tylko zapewnia zróżnicowane, otwarte, dostępne i zhumanizowane krajobrazy, ale też rolnicy tworzą konieczną wstępną infrastrukturę;

h) społeczną - poprzez zapewnienie podstawowego utrzymania osobom wchodzącym w skład gospodarstwa;

i) usługową - realizowaną poprzez takie działania, jak: transport lokalny, produkowanie kompostu, usługi turystyczne, handel itp.

${ }_{4}^{4}$ T. Hunek, Modelowanie plasowania sektora rolnego Polski w poszerzonej Unii-25, w: Perspektywy rolnictwa Polski w UE-25, „Wieś Jutra” 2006, nr 37, s. 17-20. 
Tabela 1. Cele szczegółowe i priorytety SZR WRR 2012-2020

\begin{tabular}{|c|c|}
\hline Cel szczegółowy strategii & Priorytety \\
\hline $\begin{array}{l}\text { Wzrost jakości } \\
\text { kapitału ludzkiego, } \\
\text { społecznego, zatrudnienia } \\
\text { i przedsiębiorczości na } \\
\text { obszarach wiejskich (OW) }\end{array}$ & $\begin{array}{l}\text { - podnoszenie umiejętności, poziomu wykształcenia oraz wzrost } \\
\text { mobilności zawodowej mieszkańców OW, } \\
\text { - zwiększenie zatrudnienia mieszkańców OW bez konieczności } \\
\text { zmiany ich miejsca zamieszkania, } \\
\text { - rozwój przedsiębiorczości i pozarolniczych miejsc pracy z wyko- } \\
\text { rzystaniem potencjału endogenicznego OW, } \\
\text { - zapobieganie wykluczeniu społecznemu i jego ograniczanie oraz } \\
\text { aktywizacja mieszkańców OW }\end{array}$ \\
\hline $\begin{array}{l}\text { Poprawa warunków życia } \\
\text { na OW oraz poprawa ich } \\
\text { dostępności przestrzennej }\end{array}$ & $\begin{array}{l}\text { - rozwój infrastruktury gwarantującej bezpieczeństwo energetyczne, } \\
\text { sanitarne i wodne na OW, } \\
\text { - rozwój infrastruktury transportowej gwarantującej dostępność } \\
\text { transportową OW, } \\
\text { - budowa i rozwój infrastruktury i technologii umożliwiających } \\
\text { mieszkańcom OW korzystanie z technologii ICT o wysokim stan- } \\
\text { dardzie i dostęp do niej, } \\
\text { - rozwój infrastruktury społecznej zapewniającej mieszkańcom OW } \\
\text { dostęp do dóbr i usług publicznych, } \\
\text { - rozwój infrastruktury bezpieczeństwa na OW }\end{array}$ \\
\hline $\begin{array}{l}\text { Bezpieczeństwo } \\
\text { żywnościowe }\end{array}$ & $\begin{array}{l}\text { - utrzymanie i poprawa jakości bazy produkcyjnej rolnictwa i rybac- } \\
\text { twa, } \\
\text { - wytwarzanie wysokiej jakości, bezpiecznych dla konsumentów } \\
\text { produktów rolno-spożywczych, } \\
\text { - przestrzeganie/stosowanie zasad uczciwej konkurencji na wspólno- } \\
\text { towym i globalnym rynku rolno-spożywczym, } \\
\text { - podnoszenie świadomości i wiedzy producentów oraz konsumen- } \\
\text { tów w zakresie produkcji rolno-spożywczej i zasad żywienia }\end{array}$ \\
\hline $\begin{array}{l}\text { Wzrost produktywności } \\
\text { i konkurencyjności sektora } \\
\text { rolno-spożywczego }\end{array}$ & $\begin{array}{l}\text { - modernizacja i wzrost innowacyjności sektora rolno-spożywczego, } \\
\text { - kreowanie oraz transfer wiedzy i technologii służącej zrównoważo- } \\
\text { nemu rozwojowi sektora rolno-spożywczego, } \\
\text { - dostosowanie struktur sektora rolno-spożywczego do zmieniają- } \\
\text { cych się wyzwań w Polsce, UE i w skali globalnej, } \\
\text { - promocja oraz powiększanie rynków zbytu produktów rolno-spo- } \\
\text { żywczych }\end{array}$ \\
\hline $\begin{array}{l}\text { Ochrona środowiska } \\
\text { i adaptacja do zmian } \\
\text { klimatu na OW }\end{array}$ & $\begin{array}{l}\text { - ochrona środowiska naturalnego w sektorze rolniczym i różnorod- } \\
\text { ności biologicznej na OW, } \\
\text { - kształtowanie przestrzeni wiejskiej z uwzględnieniem ochrony } \\
\text { krajobrazu i ładu przestrzennego, } \\
\text { - adaptacja rolnictwa i rybactwa do zmian klimatu oraz ich udział } \\
\text { w przeciwdziałaniu tym zmianom, } \\
\text { - zrównoważona gospodarka leśna i łowiecka na OW, } \\
\text { - zwiększenie wykorzystania odnawialnych źródeł energii na OW }\end{array}$ \\
\hline
\end{tabular}


Od 1989 roku rolnictwo europejskie wprowadza zasady tzw. zrównoważonego rozwoju (ZR), polegającego na równorzędnym traktowaniu przez politykę gospodarczą problemów ekonomicznych, społecznych i środowiskowych (ekologicznych $)^{5}$. Odpowiedzią na wyzwania ZR jest zrównoważony rozwój obszarów wiejskich (ZR OW) i rolnictwo zrównoważone (RZ), którego ideą jest zracjonalizowanie intensywności produkcji, co wpłynie na jakość środowiska naturalnego. Typ RZ upowszechnia się przede wszystkim w krajach wysoko rozwiniętych. Na przykład na terenie UE realizuje się cele Strategii zrównoważonego rozwoju wsi, rolnictwa i rybactwa na lata 2012-2020 (SZR WRR 2012-2020) szczegółowo opisane w tabeli 1.

W pozostałej części świata, w pogoni za zwiększeniem dochodów w najbardziej zintensyfikowanych gospodarstwach, dochodzi do rabunkowej gospodarki i rozdzielenia trzech głównych celów. Priorytetem jest kierunek ekonomiczny, pozostałe są realizowane jako podrzędne.

\section{Rolnictwo społecznie zrównoważone}

W Europie coraz powszechniejsza jest koncepcja RZ, w ramach którego mieszczą się koncepcje rolnictwa integrowanego i ekologicznego ${ }^{6}$. Elementami charakterystycznymi dla tej działalności są:

- zasoby naturalne, które powinny być wykorzystywane w taki sposób, aby nie została zakłócona ich zdolność do samoodnawiania się,

- przyrost produkcji żywności następujący tylko dzięki wzrostowi produkcyjności zasobów,

- mała podatność na wahania i wstrząsy,

- zrównoważone systemy rolnicze zakładające pełną symbiozę celów produkcyjnych i ekologicznych,

- zarządzanie zasobami naturalnymi umożliwiające zaspokajanie zmieniających się potrzeb, przy jednoczesnym zachowaniu wysokiej jakości środowiska naturalnego i ochronie jego zasobów.

${ }^{5}$ G.A. Wilson, Multifunctional Agriculture: A Transition Theory Perspective, CABI, Wallingford 2007, chap. 5 .

${ }^{6}$ Koncepcja badań nad rolnictwem społecznie zrównoważonym, red. J.S. Zegar, IERiGŻ, Warszawa 2005, s. 8. 
Model RZ spełnia wymogi w 3 sferach jednocześnie, tj. ekologicznej, społecznej i ekonomicznej7. W tabeli 2 zaprezentowano cechy wpływające na rozwój RZ, dając jednak pierwszeństwo czynnikom środowiskowym. Wynika to z faktu, że system ekonomiczny jest tylko podsystemem ekosystemu.

Tabela 2. Cechy ekonomiczne, ekologiczne i społeczne wpływające na rozwój RSZ

\begin{tabular}{|c|c|c|}
\hline \multicolumn{3}{|c|}{ Rolnictwo społecznie zrównoważone } \\
\hline $\begin{array}{c}\text { I strefa } \\
\text { ekologiczna }\end{array}$ & $\begin{array}{c}\text { II strefa } \\
\text { społeczna }\end{array}$ & $\begin{array}{c}\text { III strefa } \\
\text { ekonomiczna }\end{array}$ \\
\hline $\begin{array}{l}\text { uwypuklenie cech środowi- } \\
\text { skowych, czyli propagowa- } \\
\text { nie dobrych praktyk rol- } \\
\text { nych, które przeciwdziałają } \\
\text { degradacji: } \\
\text { - wód i niedostatku wody } \\
\text { dla potrzeb rolnictwa } \\
\text { i ludzi, } \\
\text { - zmianom klimatycznym, } \\
\text { - wzrostowi popytu na } \\
\text { nieodnawialne zasoby }\end{array}$ & $\begin{array}{l}\text { uwypuklenie cech społecz- } \\
\text { nych, czyli: } \\
\text { - propagowanie wartości } \\
\text { usług środowiskowych } \\
\text { tworzonych przez gospo- } \\
\text { darstwa rolne, } \\
\text { - wkład w rozwijanie ży- } \\
\text { wotności ekonomicznej } \\
\text { i społecznej OW, } \\
\text { - wkład w rozwijanie war- } \\
\text { tości kulturowych miej- } \\
\text { scowości wiejskich oraz } \\
\text { możliwości spożytkowa- } \\
\text { nia rolniczych zasobów } \\
\text { pracy }\end{array}$ & $\begin{array}{l}\text { uwzględnia kategorie do- } \\
\text { chodowe, czyli: } \\
\text { - w skali mikro rozpatruje } \\
\text { satysfakcję z dochodu, } \\
\text { - w skali makro - wartość } \\
\text { dodaną brutto, dochód do } \\
\text { dyspozycji brutto, war- } \\
\text { tość produkcji rolniczej } \\
\text { (zwłaszcza towarowej) }\end{array}$ \\
\hline
\end{tabular}

Źródło: J. Kondratowicz-Pozorska, Ekonomiczno-organizacyjne determinanty konkurencyjności ekologicznych gospodarstw rolnych w Polsce, Polskie Towarzystwo Ekonomiczne oddział w Szczecinie, Szczecin 2013, s. 29.

Zakładając, że system ekonomiczny jest częścią ekosystemu, należy stworzyć i propagować nowy system wartości, który będzie uwzględniał nie tylko takie cele w działalności człowieka, jak zysk i użyteczność, ale przede wszystkim dobro wspólne, spełniające wymogi środowiskowe ${ }^{8}$.

${ }^{7}$ E. Karami, M. Keshavarz, Sociology of Sustainable Agriculture, w: Sociology, Organic Farming, Climate Change and Soil Science, „Sustainable Agriculture Reviews” 2010, Vol. 3, s. 19-40; R. Ghorbani, A. Koocheki, K. Brandt, S. Wilcockson, C. Leifert, Organic Agriculture and Food Production: Ecological, Environmental, Food Safety and Nutritional Quality Issues, ,Sustainable Agriculture Reviews" 2010, Vol. 3, s. 77-108.

${ }^{8}$ Idea dobra wspólnego została przedstawiona w pracy: M. Lutz, Economics for the Common Good, Routledge, London-New York 1999. 


\section{Efekty rolnictwa w obszarze gospodarczo-społecznym i ekologicznym}

Rolnictwo jako podstawowa funkcja gospodarcza OW daje zatrudnienie dużej grupie mieszkańców wsi oraz kształtuje strukturę przestrzenną terenów wiejskich. W sumie na świecie 47,3\% ludności ogółem to ludność rolnicza, a średnio 18,7\% jest czynna zawodowo w rolnictwie. W UE parametry te są znacznie niższe i wynoszą odpowiednio $26 \%$ i $2 \%$ (w Polsce $39,2 \%$ i $7,3 \%{ }^{9}$ ).

Powierzchnia użytków rolnych (UR) na świecie wynosi 4922,2 $\mathrm{mln}$ ha i - niestety - ulega powolnemu zmniejszeniu; najmniejszy areał ma Norwegia - $1 \mathrm{mln}$ ha, największy Chiny - 514,6 mln ha. Polska ma do dyspozycji 14,6 mln ha (w ostatnich 25 latach w kraju ubyło 4,2 mln ha UR). Zadaniem odpowiedzialnego rolnictwa jest dbanie o niezmniejszanie areału UR i utrzymanie jakości ziemi rolniczej w stanie niegorszym niż obecnie. Światowe zbiory produktów rolnych sięgają 2566255 tys. ton, z tego tylko $0,1 \%$ przypada na Holandię i aż $13,9 \%$ na USA. Polskie zbiory to $1,2 \%$ udziału światowego. Jednak to nie zbiory, a plony świadczą o wydajności gospodarki rolnej. Ogółem przeciętny plon wynosi 36,4 dt/ha (i stale się podnosi), przy tym najniższy zanotowano w Rosji - 18,6 dt/ha, najwyższy w Holandii - 85,5 dt/ha. W Polsce przeciętny plon wyniósł $37 \mathrm{dt} / \mathrm{ha}$. Działaniem rolnictwa na rzecz ZR jest dbanie, by intensyfikacja produkcji rolniczej nie nadwyrężyła możliwości naturalnych środowiska.

Wspieranie finansowe rolnictwa, a także wsi w państwach wysoko rozwiniętych, jest celową działalnością nastawioną na rozwój wielofunkcyjności OW. Ta wielofunkcyjność, przy zmniejszającej się roli produkcyjnej rolnictwa, ma zapewnić długotrwały, harmonijny i - co warto podkreślić - samodzielny rozwój OW w przyszłości. Ma również przeciwdziałać wykluczeniu społecznemu i ubożeniu społeczności wiejskich, które charakteryzują się względnym brakiem mobilności i najczęściej niższymi kwalifikacjami zawodowymi aniżeli mieszkańcy miast.

Rolnictwo odgrywa również ważne role społeczne i kulturowe. Dzięki zachowaniu na niektórych OW tradycyjnych metod produkcji i zagospodarowania terenu, kształtuje krajobraz kulturowy wsi obfitujący w liczne pierwotne układy ruralistyczne i zabytkowe obiekty. W odróżnieniu od mieszkańców miast, ludność wsi, a szczególnie ludność rolnicza, zachowuje i przekazuje tradycje i wielowiekowe wartości kulturowe.

Zadaniem rolnictwa przy zachowaniu perspektywy ZR jest jednoczesne godzenie interesu produkcyjnego (produkcja produktów rolnych, w tym przede wszyst-

\footnotetext{
9 Dane w artykule pochodzą z Rocznika Statystycznego Rolnictwa 2014, GUS, Warszawa 2015, s. $386-445$.
} 
kim żywności, zapewnienie bezpieczeństwa żywnościowego, produkcja bezpiecznej żywności) z możliwościami środowiska naturalnego (dbałość o kondycję fizykochemiczno-biologiczną gleby, wody i powietrza, nieumniejszenie żyzności gleb w teraźniejszości i przyszłości, dbałość o zachowanie bioróżnorodności fauny i flory). Między innymi dlatego w Europie dynamicznie rozwija się rolnictwo zintegrowane, precyzyjne i ekologiczne ${ }^{10}$.

Cytując J. Wilkina, rolnictwo można porównać do lasu. Z obliczeń ekonomistów wynika, że drewno stanowi $5 \%$ do $10 \%$ wartości lasu. Na pozostałe $90 \%$ składają się inne czynniki: drzewa pochłaniają dwutlenek węgla, regulują wilgoć, są elementem krajobrazu, zapewniają bioróżnorodność, są miejscem wypoczynku i turystyki etc. Podobnie jest z rolnictwem. ono wytwarzane przez niego produkty to tylko niewielka część jego wartości. Zrezygnowanie z rolnictwa w danej gospodarce oznaczałoby nie tylko konieczność sprowadzania żywności i utratę bezpieczeństwa żywnościowego, ale też trudne do oszacowania skutki ekologiczne, kulturowe, społeczne. Zatem rolnictwo wspiera się, by po prostu istniało ${ }^{11}$. Zniknięcie rolnictwa oznaczałoby jednocześnie zniknięcie wielu dóbr publicznych, bez których teraźniejsza i przyszła egzystencja człowieka byłaby niemożliwa ${ }^{12}$.

\section{Podsumowanie}

Wartość produkcji płodów rolnych w stosunku do wartości produkcji w pozostałych sektorach (opisywana przez udział w tworzeniu PKB) ulega systematycznemu spadkowi. Współcześnie przyjmuje się, że udział rolnictwa, przemysłu i usług w ogólnej wartości produkcji na świecie wynosi odpowiednio 10\%:30\%:60\%. Zmniejszająca się rola sektora rolnictwa w gospodarce państw wysoko rozwiniętych dotyczy przede wszystkim funkcji produkcyjnej. Natomiast podnosi się rangę wszystkich pozostałych, wśród których szczególne miejsce zajmuje funkcja ekolo-

${ }^{10}$ E. Majewski, Trwaty rozwój i trwate rolnictwo, SGGW, Warszawa 2008, s. 20-50.

${ }^{11}$ J. Wilkin, op.cit.

${ }^{12}$ Do dóbr publicznych zależnych od rolnictwa zalicza się: zachowanie bioróżnorodności, utrzymanie i poszanowanie krajobrazu, zapewnienie długotrwałej funkcjonalności gleb (prowadzenie działalności proekologicznej i agrotechniki), zapewnienie dobrostanu i zdrowia zwierząt. Ponadto: jakość i dostępność wody, zapobieganie powodziom, wykorzystanie energii wodnej, jakość powietrza i stabilność klimatu, witalność obszarów wiejskich, rozwój infrastruktury na omawianych terenach, a także podtrzymanie tradycji i kultury na obszarach wiejskich. 
giczna, ochrony środowiska, kształtowania krajobrazu, regionalna i usługowa. UE, USA, Norwegia i Japonia uznały wręcz, że rola środowiskowo-społeczna i usługowa rolnictwa jest tak ważna dla rozwoju obecnych i przyszłych pokoleń, że należy finansowo wesprzeć rozwój rolnictwa i umocnić wielofunkcyjny rozwój OW. Należy też rozpocząć kampanię uświadamiającą wszystkie państwa na świecie (bez względu na ich sytuację ekonomiczną), że rolnictwo to nie tylko produkcja płodów rolnych, ale działalność, która tworzy i dba o warunki do egzystencji człowieka na Ziemi.

\section{Literatura}

Adamowicz M., Wielofunkcyjne rolnictwo w rozwoju obszarów wiejskich, w: Rolnictwo a rozwój obszarów wiejskich, red. M. Kłodziński, W. Dziun, IRWiR PAN, Warszawa 2005.

Ghorbani R., Koocheki A., Brandt K., Wilcockson S., Leifert C., Organic Agriculture and Food Production: Ecological, Environmental, Food Safety and Nutritional Quality Issues, „Sustainable Agriculture Reviews” 2010, Vol. 3.

Haman J., Hołownicki R., Michałek R., Żmija J., Misja nauk rolniczych w rozwoju polskiego sektora rolno-spożywczego, „Inżynieria Rolnicza” 2012, z. 4 (139), t. 1.

Hunek T., Modelowanie plasowania sektora rolnego Polski w poszerzonej Unii-25, w: Perspektywy rolnictwa Polski w UE-25, „Wieś Jutra” 2006, nr 37.

Karami E., Keshavarz M., Sociology of Sustainable Agriculture, w: Sociology, Organic Farming, Climate Change and Soil Science, „Sustainable Agriculture Reviews” 2010, Vol. 3.

Koncepcja badań nad rolnictwem społecznie zrównoważonym, red. J.S. Zegar, IERiGŻ, Warszawa 2005.

Kondratowicz-Pozorska J., Ekonomiczno-organizacyjne determinanty konkurencyjności ekologicznych gospodarstw rolnych w Polsce, PTE, Szczecin 2013.

Lutz M., Economics for the Common Good, Routledge, London-New York 1999.

Majewski E., Trwały rozwój i trwate rolnictwo, SGGW, Warszawa 2008.

Rocznik Statystyczny Rolnictwa 2014, GUS, Warszawa 2015.

Strategia zrównoważonego rozwoju wsi, rolnictwa i rybactwa na lata 2012-2020, MRiRW, Warszawa 2011.

Wilkin J., Wilkin o 25-leciu: polskie rolnictwo opłaca się dotować, http://wyborcza. pl/1,91446,16068282,Wilkin_o_25_leciu_polskie_rolnictwo_oplaca_sie_dotowac. html \#ixzz3WoHqZEaI (dostęp 8.04.2015).

Wilson G.A., Multifunctional Agriculture: A Transition Theory Perspective, CABI, Wallingford 2007, chap. 5. 


\title{
THE ROLE OF AGRICULTURE IN THE CREATION OF SUSTAINABLE DEVELOPMENT
}

\begin{abstract}
The article presents the contribution of agriculture to the creation of sustainable development. The analysis was performed in economic, social and environmental significance.

Translated by Jolanta Kondratowicz-Pozorska
\end{abstract}

Keywords: sustainable agriculture, sustainable development, functions of agriculture JEL code: Q1 